\title{
Sociological Investigation into the Nexus Of Poverty, Unemployment and Leadership in Nigeria
}

\author{
Anthony Abayomi Adebayo \\ Department of Sociology, Federal University, Oye-Ekiti, Ekiti State. Nigeria \\ Email: adebayo_nthny@yahoo.com
}

\section{Doi:10.5901/mjss.2014.v5n16p578}

\begin{abstract}
Poverty and unemployment are stark realities confronting the majority of the populace in the Nigerian state. The statistics to this effect present a worrisome situation, when juxtaposed with the abundant natural resources available to the nation. The National Bureau of Statistics has said that 112.519 million Nigerians live in relative poverty conditions, while the statistics from Manpower Board and National Bureau of Statistics showed that Nigeria has 64 million people unemployed. This study examined how the low quality of leadership in the country since independence has created this sorry state. The study proffered various measures that could put an end to the continued perpetuation of bad leadership and thus liberate the people from the brutal web of excruciating poverty and joblessness.
\end{abstract}

Keywords: Poverty, Unemployment, Natural Resources, Leadership, Corruption

\section{Introduction}

Nigeria is the most populous country in Africa and the eight in the world with a population of over 140 million people by 2006 census. With a nominal GDP of $\$ 207.11$ billion and per capita income of $\$ 1,401$ it has the second largest economy in Africa (Salami, 2011). As impressive as these figures may appear, it has not translated to poverty reduction and unemployment for the populace. It is a fact that the enclave called Nigeria is blessed with abundant natural resources. Since the time of the oil boom, the nation has gotten more than $\$ 500$ billion. The huge revenue from oil and other sources of revenue notwithstanding, a vast majority of the people still remain poor and live below $\$ 1$ dollar a day. This is a grave contradiction. It is a clear situation of suffering in the midst of plenty. The National Bureau of Statistics has said that 112.519 million Nigerians live in relative poverty conditions. The deteriorating trends in Nigeria governance from military to democratic dispensation has been the most daunting challenges creating depressed economy, high poverty and unemployment rates, infrastructure decay, endemic corruption, human rights abuses and several manifestations of a failing state. Beneath these multiple developmental problems of Nigeria is a fundamental crisis of leadership and good governance that can be attributed in the main to a history characterized by corruption, social injustice and political instability. Nigerians have seen a number of ineffective governments with various leaders betraying the trust of the people and people have no say over how they are governed and or how accountable their government is to them (Yusuf, 2010).

As Walter Rodney (1972) notes; "indicator of good governance and societal development depends on affirmative answers to three questions: what has been happening to poverty? what has been happening to unemployment? and what has been happening to inequality? If all these three have declined from higher levels, then beyond doubt this has been a period of development and indicator of good governance". But this is not the case in Nigeria. Rather, poverty and unemployment have been on a steady rise in the polity, despite the enormous human and material resources at the nation's disposal due to mismanagement. Therefore according to Yusuf (2010), a continuous decline in the quality of governance in Nigeria therefore calls for building political leadership based on competence, commitment, patriotism, acceptance and self-denial. Public officials must therefore provide leadership that brings about a change in behaviour, as leadership is indeed paramount to good governance. This is because at the heart of Nigeria multiple development problems are the fundamental crisis of leadership and governance that can be attributed in the main to a history characterized by corruption, social injustice and political instability. The result has been the continued marginalization of the Nigerian people, intensification of poverty, underdevelopment of the economy and corruption. Nigeria has a huge natural-resource base and also has the potential to translate this into sustainable economic growth that would drastically reduce poverty and make the country a strong partner in the global comity of nations. Despite its potential, the country has not been particularly successful in using its resources for the general good and sustainable development. As a result, 
poverty and unemployment are twin realities that have consistently tormented a vast majority of the citizenry in Nigeria. This has also led to increase in criminal activities and terrorism, which has further pushed the country down the ladder.

\section{Statement of the Problem}

Since independence, all efforts at national development have not yielded the desired results. In spite of several changes in government and leadership, the country remains under-developed; and the quality of life of most Nigerians has remained relatively low (Soyombo, 2006). Nigeria is a country blessed with abundant natural resources. Nigeria is the most populous country in Africa and the eight in the world with a population of over 140 million people by 2006 census. With a nominal GDP of \$207.11 billion and per capita income of \$1,401, it has the second largest economy in Africa (Salami, 2011). These impressive figures will surely appear extraneous and unrealistic to the average Nigerian. The recorded proceeds from the country resources, especially oil, have not translated into prosperity in the lives of the citizenry. The majority remains poor and employed, while corrupt and incompetent leadership continues to hold the country to ransom. The root cause of endemic poverty and unemployment, despite the potentials of the country for growth, is traced to the dearth of quality leadership which has continued to plague the nation since independence.

\section{Objectives of the Study}

The study aims to point out that leaders in Nigeria since independence have largely failed the people, especially as it affects institutionalization of ravaging poverty and unemployment in Nigeria. The study is to reveal how gross incompetence and corruption of the leaders has led to bad governance which has further dragged the country further down into the pit of underdevelopment, and also to proffer solution to the problem of unaccountable leadership that breeds poverty and unemployment in Nigeria.

\section{Methodology}

The study relies on secondary data from the National Bureau of Statistics, National Assembly and other secondary sources, in order to obtain data on the poverty and employment index in Nigeria.

\section{Conceptual Clarifications}

The concepts of poverty, unemployment and leadership have been severally defined over time in literature by many scholars. The Human Development Report (1997), defined poverty as deprivation in the valuable things that a person can do or be. In other words, poverty is a socio-economic condition of a person's inability to adequately cater for his basic needs of survival. The World Bank Report (2001), classified poverty in terms of lack of access to resources by individuals which leads to a state of powerlessness, helplessness and despair, inability to subsist and protect oneself against economic shocks, social, cultural and political discrimination and marginalization among others. The National Policy on Poverty Eradication in Nigeria (2000), enumerates the attributes of poverty as follows: not having enough food to eat, poor nutrition, unfit housing, high rate of infant mortality, low life expectancy, inadequate health care, lack of productive assets, lack of economic infrastructure. Furthermore, the World Bank (2003) further defined poverty as a denial of choices and opportunities, a violation of human dignity. It means lack of basic capacity to participate effectively in society. It means not having enough to feed and clothe a family, not having a school or clinic to go to; not having the land on which to grow one's food or a job to earn one's living and not having access to credit. It means insecurity, powerlessness and exclusion of individuals, households and communities. Chronic poverty is considered the component of total poverty that is static and transitory poverty component that is attributable to the inter-temporal variability (Jalan and Ravallion, 1996). The isolation of the process underlying chronic and transitory poverty is considered essential in understanding the extent to which each poverty type may obscure the other or even distort the effects of government anti-poverty programmes. A national poverty survey carried out indicates that the high tropic areas have moderate poverty while the northern regions have poverty levels that are as high as 60 percent (NBS, 2009; Ayedogbon, 2012). The average national poverty incidence indicates that this situation has not improved during the last 20 years in a majority of Sub-Saharan African countries.

The International Labour Organization (ILO) defines the unemployed as number of the economically active population who are without work but available and seeking work, including people who have lost their jobs and those who have voluntarily left work. Simply put, unemployment describes the condition of people who are without jobs (Okafor, 
2011). According to the National Bureau of Statistics (2009), the labour force of a country is a set of people or citizens who are willing and are able to make available at any given point in time their efforts for gainful employment, while the unemployed are the individuals with no work, but are looking for work at the time of any study. Various forms of unemployment have been identified by scholars. These include seasonal, frictional, cyclical, and structural unemployment (Adebayo, 1999; Damachi, 2001; Hollister \& Goldstein, 1994; Todaro, 1992). Unemployment is a global trend but it occurs mostly in the developing countries of the world, with attendant social, economic, political and psychological consequences. Thus massive youth unemployment in any country is an indication of far more complex problems (Okafor, 2009). The ILO (2007) report showed that the proportion of world unemployment are steadily increasing and that the number of those without jobs remained at an all time high of more than 195 million or 6.3 percent in 2007. For instance, during the period (2007), the Middle East and North Africa were the regions with the highest unemployment rate in the world at 12.2 percent, followed by Sub-Saharan Africa at nearly 10 percent. East Asia's unemployment rate of 3.6 percent remained the lowest. The report affirmed that population growth especially in South Asia, the Middle East, North Africa and sub-Saharan Africa was putting pressure on job creation (Adebayo, 2013). Unemployment as a global concern is of more dire consequence for youth employment. Global youth unemployment rate was projected at 12.7 percent in 2012. This portends immense dangers when understood from the point of view that young people are the next generation of potentially productive economic and social actors. In Africa, youth unemployment has been a major problem giving rise to other criminal tendencies in the youths and threatens the social-economic peace and stability of the continent (Ajufo, 2013; Adebayo, 2013). Unemployment has been categorized as one of the serious impediments to social progress. Apart from representing a colossal waste of a country's manpower resources, it generates welfare loss in terms of lower output thereby leading to lower income and well-being (Raheem, 1993). The need to avert the negative effects of unemployment on poverty has made the tackling of unemployment problems to feature very prominently in the development objectives of many developing countries.

Leadership has been described as "a process of social influence in which one person can enlist the aid and support of others in the accomplishment of a common task. A leader is also simply as somebody whom people follow, or as somebody who guides or directs others, while others define leadership as "organizing a group of people to achieve a common goal. Leadership style plays a key role in uplifting any human society or holding down the wheel of progress. It is the foundation that determines progress or the absence of it. According to Mullins (1996), as quoted in Yusuf, leadership is a process in which the leader and followers interact such that the leader influences the actions of the followers towards the achievement of certain aims or objectives. Thus it is the ability of influence the behaviour of others, or exerts influence within working group in other to achieving group task or organisation objective. For Anazodo et al, (2012) leadership is "a process of influencing, directing and co-coordinating the activities of organized groups towards goal setting, goal achievement, and problem solving, that it necessarily involves taking initiative or initiating new structures and new procedures and that is imperatively a function of the leader and the situational variable." The followers (subordinates) perceive the leadership as having certain attributes or characteristics that endeared him/her to control or exert influence over them. Therefore, leadership, by concept, is a non-coercive capacity (i.e. is not the use of instrument of delegated power or authority), and followers (subordinate) willing consent to be influenced or directed by the leadership. There is a widely held belief that leadership is one of the factors that determines whether a group, an organization or even a nation will be successful (Bass, 1990).

\section{Theoretical Framework}

Structural functionalism or simply functionalism, is a framework for building theory that sees society as a complex system whose parts work together to promote solidarity and stability. For Talcott Parsons, "structural-functionalism" came to describe a particular stage in the methodological development of social science, rather than a specific school of thought. The structural functionalism approach is a macro-sociological analysis, with a broad focus on social structures that shape society as a whole. This approach looks at society through a macro-level orientation, which is a broad focus on the social structures that shape society as a whole, and believes that society has evolved like organisms, with attention to both social structure and social functions. Functionalism addresses society as a whole in terms of the function of its constituent elements. A common analogy, popularized by Herbert Spencer, presents the parts of society as "organs" that work toward the proper functioning of the "body" as a whole. In the most basic terms, it simply emphasizes "the effort to impute, as rigorously as possible, to each feature, custom, or practice, its effect on the functioning of a supposedly stable, cohesive system" (en.wikipedia.org/wiki/Structural_functionalism).

Functionalism compares human societies to living organisms and maintains that just as a living organism must ensure that parts work together in unison to ensure survival and life, every part of the society must function in harmony. 
For example, for any human being to remain alive, the heart, brain, liver, kidney, hands, legs, intestine, eyes and other parts of the body must all function well and proportionately to guarantee the wellbeing of the person. If any of these organs of the body does not perform well, sickness and even death may occur. For instance, if the heart ceases to function thereby putting a stop to the supply of blood to the body, the person dies and issues like heart attack or cardiac arrest begin to arise. The same way parts of human or living organism must function harmoniously to ensure survival of the organism, so also must every part of society function in agreement for a well ordered and prosperous society. For societies to exist, unify and make existence and human interaction orderly, institutions and structures are created that regulate behavioural patterns through norms and values that must be inculcated by the society and internalized by members through socialization process. Social structures are patterned relationships among members that have endured over time, so they are not arbitrary and can pattern human actions to create modal behaviour patterns (Akanle and Olutayo, 2013).

Within the functionalist framework, institutions and individuals must resonate the norms and values of the society to ensure acceptable behaviour since conformity is esteemed while deviation is considered inimical to societal survival. This connotes the fact that leaders and every member of the society must adopt the expected behavioural pattern in conformity to the realization of the goals of the society. The leadership class as an important organ of the society must live up to role expectations in the society for the society to prosper. The leadership of any society is charged with the responsibility of chart the course of development, to which the citizenry subscribes for society's goal attainment. Consequently, a focused, selfless and competent leadership is essential for the growth of any society.

\section{Poverty in Nigeria}

Today, although Nigeria should be one of the richest countries in the world with vast oil reserves, yet over $65 \%$ of the country's populations live under the poverty line and half of those live in abject poverty. The magnitude and expansion of poverty in Nigeria and the threat it poses makes it one of the biggest challenges in the nation today. The rate of poverty in Nigeria has worsened since the late 1990s, to the extent that the country is now considered as one of the twenty poorest countries of the world. According to Omotola (2008), about 70 percent of the population now lives in abject poverty. There is also the geographical dimension of poverty in Nigeria. According to Aigbokhan (2000), poverty is higher in the rural areas than in urban areas. In 2004, the urban population with access to water was 67 percent, while it was 31 percent in the rural areas. In terms of sanitation services, 53 percent of the urban population had access to sanitation services and 36 percent in the rural areas. This is worse than the situation in Cameroon, South Africa, Zambia, and Zimbabwe (World Bank, 2008). Given the figures above, the rural dwellers in Nigeria grapple with difficult living conditions compared to the urban dwellers. This explains why there is prevalence of diseases among the rural poor in the country (Segun, 2010).

Poverty in Nigeria is especially severe in the rural areas, where social services and infrastructure are limited or non-existent. Majority of those who live in rural areas are poor and depend on agriculture for food and income. The causes of rural poverty in Nigeria include neglect of rural infrastructure, environmental problems, civil unrest, inequality in income distribution, economic orientation, rapid increase in population, over-dependence on oil exports and domestic policy mistakes. Part of this is because of rampant corruption in urban areas and the ongoing failure of repeated programs initiated by successive governments to address the poverty issue. Many of these programs have been dismissed as mere slogans. Few funds allocated to poverty campaigns have not trickled down to the masses due to inefficiency, lack of knowledge and corruption, leaving the $90 \%$ of the rural community to rely on subsistence farming with almost half struggling to make a living on small holdings barely one hectare in size (Sodangi, 2011). The gross lack of productivity in the agricultural sector is the root cause of rural poverty in Nigeria, as the oil revenues largely bypass those living and working outside that industry. The failure of agriculture in Nigeria is often blamed on the federal system; with the central government planning ignored or by passed by regional governments. What is clear, however, that as the agriculture industry has declined decade after decade, the ability to provide food for the family and sell on the excess has diminished year by year, fuelling poverty in Nigeria and of course, malnutrition.

The poverty situation in Nigeria is quite disturbing. Both the quantitative and qualitative measurements attest to the growing incidence and depth of poverty in the country (Okunmadewa, et al., 2005). This situation however, presents a paradox considering the vast human and physical resources that the country is endowed with. It is even more disturbing that despite the huge human and material resources that have been devoted to poverty reduction by successive governments, no noticeable success has been achieved in this direction. Although, predicted poverty reduction scenarios vary greatly depending upon the rate and nature of poverty related policies, actual evidence suggests that the depth and severity of poverty is still at its worst in Nigeria. Available statistics reveals that the poverty incidence in Nigeria has been on the increase since the 1980s. As reported by the UNDP (2010), between 1980 and 1996, the percentage of the core 
poor rose from 6.2 percent to 29.3 percent, and declined to 22.0 percent in 2004. As Garba (2006) opines, the world's per capita income as of 2003 was $\$ 7,140$. Comparing this to Nigeria's per capita income of $\$ 290$ makes the country one of the poorest in the world. In a summary, the poor in Nigeria is that average citizen that has little or often nothing to feed on, lives under very poor, unhygienic conditions, cannot afford the basic needs of life including clothing, shoes and medical care; whose children are always victims of incessant fees-drive from elementary to secondary schools levels. The poverty is further reflected on the children who often go to school in tattered dresses often without shoes with only exercise books but essentially without necessary reading books. Being a victim of environmental circumstances, he is not fatalistic but hopeful, always working up to providence to burst the vicious circle, struggling to train the children who are hoped to be the possible potent outlet from the grips of poverty.

As a result of the failure of leadership and governance in Nigeria, the rate of poverty continues to soar as the year goes by. The table below further presents a vivid reality of poverty in Nigeria.

Table 1: Poverty Profile in Nigeria over the years

\begin{tabular}{|c|c|c|c|c|c|}
\hline Levels & 1980 & 1985 & 1992 & 1996 & 2004 \\
\hline NATIONAL & 27.2 & 46.3 & 42.7 & 65.6 & 54.4 \\
\hline Urban & 17.2 & 37.8 & 37.5 & 58.2 & 43.2 \\
\hline Rural & 28.3 & 51.4 & 46.0 & 69.3 & 63.3 \\
\hline \multicolumn{6}{|l|}{ ZONE } \\
\hline South South & 13.2 & 45.7 & 40.8 & 58.2 & 35.1 \\
\hline South East & 12.9 & 30.4 & 41.0 & 53.5 & 26.7 \\
\hline South West & 13.4 & 38.6 & 43.1 & 60.9 & 43.0 \\
\hline North Central & 32.2 & 50.8 & 46.0 & 64.7 & 67.0 \\
\hline North East & 35.6 & 54.9 & 54.0 & 70.0 & 72.2 \\
\hline North West & 37.7 & 52.1 & 36.5 & 77.2 & 71.2 \\
\hline \multicolumn{6}{|l|}{ Size of Household } \\
\hline $0-1$ & 0.2 & 9.7 & 2.9 & 13.1 & 12.6 \\
\hline $2-4$ & 8.8 & 19.3 & 19.5 & 51.5 & 39.3 \\
\hline $5-9$ & 30.0 & 50.5 & 45.4 & 78.4 & 57.9 \\
\hline $10-20$ & 51.0 & 71.3 & 66.1 & 88.5 & 73.3 \\
\hline $20+$ & 80.9 & 74.9 & 93.3 & 93.6 & 90.7 \\
\hline \multirow{2}{*}{\multicolumn{6}{|c|}{$\begin{array}{l}\text { Educational Level of } \\
\text { Household head }\end{array}$}} \\
\hline & & & & & \\
\hline No Education & 30.2 & 51.3 & 46.4 & 72.6 & 68.7 \\
\hline Primary & 21.3 & 40.6 & 43.3 & 54.4 & 48.7 \\
\hline Secondary & 7.6 & 27.2 & 30.3 & 52.0 & 44.3 \\
\hline Higher than Secondary & 24.3 & 24.2 & 25.8 & 49.2 & 26.3 \\
\hline
\end{tabular}

Source: National Bureau of Statistics, 2011.

Table 1 above shows that between 1980 and 2004, the rate of poverty has experienced significant growth in spite of the enormous resources available to the country and various poverty alleviation programmes embarked upon in the country over the years. It must, however, be acknowledged that between 1996 and 2004, some zones in the country recorded some marginal reduction in the poverty rate, but overall the rate of poverty has increased, especially when 1980 is put side by side with 2004, it would be revealed that there has been a phenomenal increase.

Furthermore, statistics from the National Assembly reveals that the poverty incidence increased from $15 \%$ at independence (1960) to $27.2 \%$ in 1980 and $46.3 \%$ in 1985 but reduced to $42.7 \%$ in 1992, while by 1999 it increased to $65.6 \%$ and further reduced to $54.4 \%$ in 2004 . Despite the huge revenue derived from oil, the poverty incidence has been on the increase in Nigeria. The GDP growth rate increased from 2.8\% in 1989 to $6 \%$ in 2000, while poverty rate was $54.4 \%$ and the inflation rate stood at $13.7 \%$. By 2009 , the GDP growth rate stood at $7.22 \%$ while inflation rate was $11.2 \%$; yet despite the significant increase in the GDP, there is no reduction in the number of poor people in the country. Poverty is widespread, severe and varies among the geo-political zones of the country. The extremely poor do not have access to food, shelter, treated water, good healthcare and basic education (NASS Statistics, 2009; Yusuf, 2010).

This reality of unabated poverty of the citizenry as exemplified in the above official figures remains a problem that requires focused, selfless and competent leadership to eradicate or reduced to the barest minimum. This is because, for too long, people have been short-changed by dishonest leadership and irresponsible elite. While majority of Nigerians monthly salaries hardly last a week, as the inflationary trends raises the prices of food, transportation, healthcare, everincreasing school fees, rent and rates and other necessities, the elites in society lead opulent lifestyles, perpetuated by corruption. Human development indices for Africa's second largest economy continue to be appalling despite the country's bountiful resources, escalating oil fortunes and a vigorous reforms programme initiated after the return of democracy in 1999. A 2007 UNDP survey on poverty and extreme deprivation of 108 countries ranked Nigeria at the 80th position, giving it a Human Poverty Index of 37.3 "among the lowest for the entire continent. For a country that earns an estimated $\$ 2.2$ million in daily petrodollar revenue, these figures reflect an impudent malaise that has invaded every 
aspect of Nigerian life (Osalor, 2010).

\section{Unemployment in Nigeria}

Available statistics show that unemployment is a reality bedevilling the Nigerian state. Despite the supposed prosperity of the country, a significant number of the citizenry still remain employed. The table below further buttress this assertion.

Table 2: National Unemployment Rates by States as at 31 ${ }^{\text {st }}$ December $2006-2010$

\begin{tabular}{|c|c|c|c|c|c|}
\hline States & 2006 & 2007 & 2008 & 2009 & 2010 \\
\hline All Nigeria & $13.7 \%$ & $14.6 \%$ & $19.7 \%$ & $21.4 \%$ & $23.9 \%$ \\
\hline Abia & 13.5 & 10.9 & 14.5 & 22.8 & 11.2 \\
\hline Adamawa & 17.9 & 11.9 & 29.4 & 24.6 & 33.8 \\
\hline Akwa Ibom & 15.3 & 13.5 & 34.1 & 27.7 & 18.4 \\
\hline Anambra & 10.8 & 11.1 & 16.8 & 10.8 & 12.2 \\
\hline Bauchi & 23.9 & 7.3 & 37.2 & 27 & 41.4 \\
\hline Bayelsa & 16 & 6.9 & 41.5 & 27.4 & 23.9 \\
\hline Benue & 10.8 & 67.4 & 8.5 & 6 & 14.2 \\
\hline Borno & 5.8 & 7.8 & 27.7 & 26.7 & 29.1 \\
\hline Cross River & 16.9 & 11.8 & 14.3 & 27.9 & 18.2 \\
\hline Delta & 13.8 & 18.9 & 18.4 & 27.9 & 27.2 \\
\hline Ebonyi & 10.9 & 11.5 & 12 & 25.1 & 23.1 \\
\hline Edo & 8.6 & 5.1 & 12.2 & 27.9 & 35.2 \\
\hline Ekiti & 8.7 & 15.6 & 20.6 & 28 & 12.1 \\
\hline Enugu & 20 & 11.5 & 14.9 & 28 & 25.2 \\
\hline Gombe & 15.6 & 10.5 & 32.1 & 27.2 & 38.7 \\
\hline Imo & 21.5 & 7.6 & 20.8 & 28.1 & 26.1 \\
\hline Jigawa & 21.6 & 17.4 & 26.5 & 14.3 & 35.9 \\
\hline Kaduna & 14.1 & 5.9 & 11.6 & 12.4 & 30.3 \\
\hline Kano & 19.4 & 12.7 & 27.6 & 14.7 & 21.3 \\
\hline Katsina & 19.3 & 5.8 & 37.3 & 11 & 28.1 \\
\hline Kebbi & 15.2 & 11.8 & 12 & 10.7 & 25.3 \\
\hline Kogi & 12.5 & 16.5 & 19 & 9.5 & 14.4 \\
\hline Kwara & 7.5 & 16.4 & 11 & 2.7 & 7.1 \\
\hline Lagos & 15.5 & 10.2 & 19.5 & 27.6 & 8.3 \\
\hline Nassarawa & 8.1 & 7.6 & 10.1 & 3.4 & 36.5 \\
\hline Niger & 3.6 & 17 & 28 & 11.7 & 39.4 \\
\hline Ogun & 2.3 & 3.9 & 8.5 & 27.8 & 22.9 \\
\hline Ondo & 6.7 & 5.8 & 14.9 & 28 & 12.5 \\
\hline Osun & 2.7 & 6.3 & 12.6 & 27.6 & 3.0 \\
\hline Oyo & 4.3 & 6.5 & 14.9 & 27.7 & 8.9 \\
\hline Plateau & 2.9 & 8.7 & 7.1 & 10.4 & 25.3 \\
\hline Rivers & 25 & 4.7 & 27.9 & 27.8 & 25.5 \\
\hline Sokoto & 6.4 & 12.1 & 22.4 & 15.9 & 17.9 \\
\hline Taraba & 14 & 5.9 & 26.8 & 24.7 & 12.7 \\
\hline Yobe & 13.6 & 19.9 & 27.3 & 26.2 & 35.6 \\
\hline Zamfara & 50.8 & 12.8 & 13.3 & 14.5 & 42.6 \\
\hline$F C T$, Abuja & 16.4 & 16.4 & 21.5 & 11.8 & 21.1 \\
\hline
\end{tabular}

Source: National Bureau of Statistics, 2011.

Table 3: Unemployment Rate by Educational Level, Age Group and Gender, Nigeria 2009 - 2010

\begin{tabular}{|l|llllccc|}
\hline EducationalLevel & \multicolumn{4}{|c}{ 2009 } & \multicolumn{3}{c|}{ 2010 } \\
& Urban & Rural & Composite & Urban & Rural & Composite \\
\hline Never Attended & 19.2 & 17.7 & 17.9 & 19 & 22.8 & 22.4 \\
Below Primary & 24.9 & 23.1 & 23.5 & & & \\
Primary & 21.8 & 21.8 & 21.8 & 15.5 & 22.7 & 21.5 \\
Modern School & & & & 14.5 & 27.5 & 21.5 \\
JSS & 24.5 & 22.4 & 23.1 & 16.6 & 36.9 & 33.4 \\
VocationaV/Commercial & 27.9 & 24.1 & 25.7 & 34.5 & 27 & 28.7 \\
SSS & 24.2 & 23.6 & 23.9 & 13.9 & 22.5 & 20.1 \\
NCE/OND/Nursing & 22.3 & 20.4 & 21.5 & 17.2 & 22.5 & 20.2 \\
B.A/B.Sc/B.Ed/HND & 24 & 21.5 & 23.1 & 16.8 & 23.8 & 20.2 \\
M.Sc/M.AMAdmin & 20.7 & 18.5 & 20.1 & 3.2 & 8.3 & 5.1 \\
TECH/PROF & & & & 5 & 27.9 & 20.6 \\
Doctorate & 19.6 & 19.6 & 19.6 & 11.1 & 7.7 & 9.1 \\
Others & 22 & 23.7 & 22.8 & 31.3 & 36.1 & 35.5 \\
Age Group & & & & & & \\
15-24 & 26 & 24.8 & 25.2 & 33.5 & 38.2 & 37.7 \\
25-44 & 46 & 39 & 42 & 16.3 & 24.1 & 22.4 \\
45-54 & 20.5 & 19 & 19.5 & 12.5 & 19.6 & 18 \\
55-64 & 22.1 & 20.5 & 21.1 & 17.8 & 22.1 & 21.4 \\
Gender & & & & & & \\
Male & 21.6 & 18.5 & 19.6 & 16.9 & 25.1 & 23.5 \\
Female & 24.2 & 23.1 & 23.5 & 17.2 & 26.1 & 24.3 \\
National & 22.8 & 20.7 & 21.4 & $\mathbf{1 7 . 1}$ & $\mathbf{2 5 . 6}$ & $\mathbf{2 3 . 9}$ \\
\hline
\end{tabular}

Source: National Bureau of Statistics, 2011. 
From Tables 2 and 3 above, according to National Bureau of Statistics (2011), the national unemployment rates for Nigeria between 2006 and 2010 showed that the number of unemployed persons constituted 13.7\% in 2006; 14.6\% in $2007 ; 19.7 \%$ in $2008 ; 21.4 \%$ in $2009 ; 23.9 \%$ in 2010 . As regards the age group, the reports shows that as at 2009 and 2010 in Nigeria, for persons between the age of 15 and 24 years, $25.2 \%$ were unemployed. For persons between the age of 25 and 44 years, $42 \%$ were unemployed. Also for persons between the age of 45 and $54,19.5 \%$ were unemployed, while for person between the age of 55 and $64,21.1 \%$ were unemployed. Furthermore, it is also evident from the table that unemployment cuts across all educational levels, age and gender.

Furthermore, for Awogbenle and Iwuamadi (2010); and Okafor (2011), the statistics from Manpower Board and national Bureau of Statistics showed that Nigeria has a youth population of 80 million, representing over $60 \%$ of the total population of the country. Also 64 million are unemployed, while 1.6 million are under-employed. For Osalor (2010), despite achieving an inspiring growth rate of $7 \%$ per annum since 2001, Nigeria remains crippled with massive unemployment levels that continue to exact a considerable toll on its socio-economic prospects. Credible data on this count is lacking for most of sub-Saharan Africa, but Abuja concedes that $70 \%$ of the population was jobless as recently as 2007. The federal government later revised the figure to just below $29 \%$ in accordance with new World Bank findings. Although the percentage drop seems incredible, it still translates to more than 40 million jobless in a country of 148 million. The implications have been especially harsh for Nigerian youths, an estimated $95 \%$ of whom are without a source of livelihood. Furthermore, according to a report in the Vanguard newspaper (December 17, 2013), the National Bureau of Statistics (NBS) on Tuesday said that 54 per cent of Nigerian youths were unemployed in 2012. This was contained in the "2012 National Baseline Youth Survey Report" issued in Abuja by the NBS in collaboration with the Federal Ministry of Youths Development. "More than half, about 54 per cent of youth population was unemployed. "Of this, females stood at 51.9 per cent compared to their male counterpart with 48.1 per cent were unemployed."

These figures only reconfirm the perception that high growth rates have failed to improve Nigeria's entrenched macro-economic deficiencies, born out of decades of failed governance, mismanagement and conflict. The downstream effects of youth unemployment are fuelling rapid alienation and social unrest across the Nigerian landscape, the immediate symptoms of which are evident in the palpable rise in organised crime, armed insurgency, vandalism and drug trafficking.

\section{Nexus of Leadership, Poverty and Unemployment in Nigeria}

According to Anazodo et al, (2012) leadership is "a process of influencing, directing and co-coordinating the activities of organized groups towards goal setting, goal achievement, and problem solving, that it necessarily involves taking initiative or initiating new structures and new procedures and that is imperatively a function of the leader and the situational variable." This means that leaders provide direction for the rest of the populace. Leaders are entrusted with the destiny of any organization. The functions of a leader include environmental monitoring, organizing subordinate activities, teaching and coaching subordinates, motivating others, and intervening actively in the group's work.

Leadership and governance go hand in hand. Good leadership leads to good governance. In other words, governance is a consequence of leadership. For Yusuf (2010) "good governance implies a situation where majority say is respected; where government strives in all its policies and actions to provide a better life for the majority; where social inequities are minimized; where all stakeholders respect the rule of law and where the conduct of government is transparent and accountability is institutionalized." Also Adamolekun (2006) views governance as the "process of exercising political power to manage the affairs of a nation." However, a more relevant definition of governance to the study was given by the World Bank as quoted in (Lawal, 2012) which defines good governance as "the means of exercising power in the management of a nation's economic and social resources for sustainable development." This is achievable through the institution of a process of high level organizational effectiveness in relation to policy formulation and implementation, especially as relates to conduct of economic and fiscal policy and its contribution to growth, stability, and public welfare. In this way, better life will be assured for the majority of the people.

It is, however, saddening to note that the crop of leaders who have emerged in the corridors of power in Nigeria since independence, have denied the nation the opportunity of good governance. Selfless leadership either by the military or civilian regimes have remained a mirage. In Nigeria today, leadership across board from local to national level is all about the well-being of the leaders and their cronies and the entrenchment of their rules by crook means. Service has thus taken the backstage and the motivation for a spring to the public offices, both elective and appointment appears to be the craze for ill-gotten wealth. Today, the most lucrative vocation is politics. It is also the easiest means of making money. The vast majority of the citizenry have remained poor while the leaders have continued to corruptly enrich themselves. High level of corruption in Nigeria has robbed the country of developing a vibrant economic base in spite of 
her abundant natural resources. Massive corruption is perpetuated in every sector and has permeated the entire social structure of Nigeria. Funds meant for development projects which could have generated employment have been misappropriated, diverted, or embezzled and stashed away in foreign banks. Endemic corruption has robbed the country of the chance of using more than $\$ 500$ billion dollars estimated revenue from the sale of oil in the last 50 years to develop a vibrant economy that would have created jobs for the youths in the various sectors of economy (Okafor, 2005). According to Kofi Annan, 2003 (then Sectary General of United Nations), as quoted in Yusuf (2010), "Corruption is an insidious scourge that impoverishes many countries, and affects us all ... it creates discrimination between different groups in a society, feeds inequality and injustice, discourages foreign growth ... it is indeed a major obstacle to political stability and successful social and economic development of any nation".

Furthermore, as quoted in Igwe (2010), Transparency International defines corruption as the misuse of entrusted power for private gain. Corruption bears heavily on economic development and contributes to the affluence of a few which leads to a situation of a few affluent amidst a sea of people who live in acute squalor. It fosters unaccountable governance as the leadership crew strives to prevent the masses from getting to know exactly how much acquired and how they are put to use. Corruption is both a cause of poverty, and a barrier to overcoming it. . . In October 2006, the then president of the World bank, Paul Wolfowitz disclosed that Nigerian officials had stolen more than $\$ 300$ billion of their nations wealth over the last forty years. For instance, Idowu and Oyinlola (2006) revealed that "Sani Abacha stole the nation blind, paralyzed the machinery of governance and pauperized the citizenry in five years of dictatorship and frenetic looting. He dipped his hands into Central Bank of Nigeria's vaults 29 times between 1993 and 1998, and stole $\$ 1.13$ billion and 413 million pounds. This did not include $\$ 386.2$ million as well as returns from fictitious and inflated contracts, which he ordered to be transferred into bank accounts abroad. As it were, he not only pocketed security votes but also engaged in direct printing of the nation's currency among other heinous acts. By the time he died in 1998, Abacha had corruptly enriched himself and the family by as much as $\$ 3$ billion lodged in more than 130 bank accounts at home and abroad." Unfortunately for the nation, the death of Abacha did not signal the end of monumental corruption by government officials in Nigeria. Rather, it has further assumed frightening dimensions. James Onanefe Ibori, former governor of Delta State, Nigeria, was jailed for 13 years on April 17, 2012 in the United Kingdom, having pleaded guilty to charges of theft of public funds, abuse of office and money laundering to the tune of $\$ 250$ million. The fact however remains that there are many others like him who have escaped the long arms of justice in Nigeria, who are walking freely or are still operating in the corridors of power today.

The increased abuses in public office have weakened the security situation in the country, intensified poverty and are manifestations of the crisis of good governance. Nigerians have seen a number of ineffective governments with various leaders betraying the trust of the people and people have no say over how they are governed and or how accountable their government is to them. The military rule undermined development of democratic institutions, culture of accountability and transparency and is characterized by the absence of citizen influence and oversight. In these conditions, good governance becomes a rare commodity; the result has been diminished economic development, reduced social cohesion, a heightened level of corruption and high state of insecurity all of which undermined political stability (Yusuf, 2010).

The brazen looting of the national treasury has become the order of the day. It is referred to turn by turn, chop I chop in governance parlance. This has led to massive unemployment, which has become a major problem tormenting the lives of Nigerian youths and this poses a serious risk to the Nigerian society. The phenomenon of youth unemployment is devastating to both the individual and the society as a whole both psychologically and economically. The magnitude of the danger which youth unemployment poses to the society is better understood when, according to Awogbenle and Iwuamadi (2010), over 64 million youths are unemployed and 1.6 million are under-employed. Unemployment causes frustration, dejection, desperation and dependency on family members and friends who also have their own problems to contend with. This precarious situation has left the youths in a vicious cycle of poverty that daily erodes their confidence and bright future, while the leaders continue to revel in the majestic splendour of stolen commonwealth. Thus the current development crisis in Nigeria can be attributed to a history of poor governance characterized by corruption and social injustice. This informed why Nigeria is in a state of ever-shaky socio-political stability due greatly in part to the pervasive poverty trends, as informed by bad governance. (Yusuf, 2010).

Leadership, through good governance, is supposed to ensure organizational effectiveness in relation to policy formulation and implementation, which will in turn contribute to economic growth, stability, and social welfare of the citizens. In contrast, however, the failure of leadership has led to the frustration and desperation that daily torments the unemployed creates a fertile crime for crime to thrive. In recent times, there have been notable adverse social, economic and political developments in Nigeria, a consequence of youth unemployment and under-employment, particularly exemplified by increasing militancy, violent crimes, kidnapping, restiveness and political instability (Ajufo, 2013). The 
scariest undertone of Nigeria's socio-economic underachievement, by far, is the steady rise in youth crime, nurtured in a climate of increasing national income and the simultaneous failure of employment-generation and poverty alleviation programmes. Armed insurgencies ravaging Northern Nigeria is now competing for space in international headlines with a proliferation of Islamic terrorist offshoots (Adebayo, 2013).

The cost of curbing the resultant criminal activities arising from poverty and unemployment is alarming. For instance, the Central Bank Governor recently disclosed that the Federal Government has spent at least N260billion on ex-Niger Delta militants between 2009 and 2013 through the amnesty programme and oil pipeline protection deals. About 248 billion has been spent through the amnesty programme to pay monthly stipends to ex-militants and on their training both in the country and abroad (Okpi, 2014). In a similar way, the budget of N921.91 billion was earmarked to combat terrorism and criminality in Nigeria in the year 2012 alone. Furthermore, Mr Kingsley Kuku, the Special Adviser to the President on Niger Delta, said in the budget defence session with the House of Representatives Committee on Niger Delta for 2014, that a total budget proposal for the Amnesty Programme for the repentant militants in the year 2014 was a whooping sum N63.28 billion. These huge funds earmarked to curtail crime could have been deployed to development programmes that the nation desperately needed.

It must be noted, however, that there have been many initiatives of government towards poverty eradication over time. However, these programmes have largely failed owing to failure of leadership, which manifested through inconsistency, corruption, lack of proper focus, lack of due diligence, favouritism and nepotism etc. Below is a presentation of some of the programmes initiated by various government regimes in Nigeria.

Table 1: Selected Government Programmes from 1972 to date

\begin{tabular}{|c|c|c|c|c|}
\hline Programmes & \begin{tabular}{|c|} 
Year \\
Established
\end{tabular} & $\begin{array}{c}\text { Head of } \\
\text { Government }\end{array}$ & Target Group & Nature of Intervention \\
\hline $\begin{array}{l}\text { National Accelerated Food } \\
\text { Production Programme (NAFPP) }\end{array}$ & 1972 & $\begin{array}{l}\text { General Yakubu } \\
\text { Gowon }\end{array}$ & Rural Farmers & To educate and empower farmers \\
\hline $\begin{array}{l}\text { Nigerian Agricultural and Co- } \\
\text { operative Bank (NACB) }\end{array}$ & 1972 & $\begin{array}{c}\text { General Yakubu } \\
\text { Gowon }\end{array}$ & Rural Farmers & Agricultural Financing \\
\hline Operation Feed the Nation (OFN) & 1979 & $\begin{array}{c}\text { General Olusegun } \\
\text { Obasanjo }\end{array}$ & $\begin{array}{c}\text { Rural Farmers and } \\
\text { dwellers }\end{array}$ & Increase food production \\
\hline $\begin{array}{l}\text { Directorate for Food, Roads and } \\
\text { Rural Infrastructure (DFRRI) }\end{array}$ & 1986 & $\begin{array}{l}\text { General Ibrahim } \\
\text { Babangida }\end{array}$ & Rural dwellers & \begin{tabular}{|l|} 
Feeders roads rehabilitation, rural \\
water supply and rural electrification
\end{tabular} \\
\hline $\begin{array}{l}\text { Better Life Programme for Rural } \\
\text { Women }\end{array}$ & 1987 & $\begin{array}{c}\text { General Ibrahim } \\
\text { Babangida }\end{array}$ & Rural Women & $\begin{array}{l}\text { Self help and Rural development } \\
\text { programme, skill acquisition. }\end{array}$ \\
\hline People's Bank of Nigeria & 1989 & $\begin{array}{l}\text { General Ibrahim } \\
\text { Babangida }\end{array}$ & $\begin{array}{l}\text { Under-privileged in } \\
\text { rural and urban } \\
\text { areas }\end{array}$ & Securing loans and credit facilities \\
\hline Family Support Programme (FSP) & 1994 & $\begin{array}{c}\text { General Sani } \\
\text { Abacha }\end{array}$ & $\begin{array}{l}\text { Families in rural } \\
\text { areas } \\
\end{array}$ & $\begin{array}{l}\text { Empowerment of rural dwellers, } \\
\text { health care and child welfare }\end{array}$ \\
\hline $\begin{array}{l}\text { Family Economic Advancement } \\
\text { Programme (FEAP) }\end{array}$ & 1998 & $\begin{array}{l}\text { General Sani } \\
\text { Abacha }\end{array}$ & Rural Dwellers & $\begin{array}{l}\text { Credit facilities to support the } \\
\text { establishment of cottage industries in } \\
\text { rural areas }\end{array}$ \\
\hline $\begin{array}{l}\text { Poverty Alleviation Programme } \\
\text { (PAP) }\end{array}$ & 1999 & $\begin{array}{l}\text { Chief Olusegun } \\
\text { Obasanjo }\end{array}$ & $\begin{array}{l}\text { The poor in the } \\
\text { society }\end{array}$ & Empowerment of the poor \\
\hline $\begin{array}{l}\text { National Poverty Eradication } \\
\text { Programme (NAPEP) }\end{array}$ & 2001 & $\begin{array}{c}\text { Chief Olusegun } \\
\text { Obasanjo }\end{array}$ & $\begin{array}{l}\text { The poor in the } \\
\text { society }\end{array}$ & Empowerment of the poor \\
\hline $\begin{array}{l}\text { National Economic Empowerment } \\
\text { and Development Strategy } \\
\text { (NEEDS) }\end{array}$ & 2004 & $\begin{array}{l}\text { Chief Olusegun } \\
\text { Obasanjo }\end{array}$ & The poor in society & $\begin{array}{l}\text { Government reformation, growing } \\
\text { private sector, access to health, } \\
\text { education, welfare, empowerment, } \\
\text { security and participatory } \\
\text { governance. }\end{array}$ \\
\hline
\end{tabular}

Source: Oladeji and Abiola, 1998; Arogundade, 2011

These programmes, though established for the purpose of poverty alleviation, seemed to have failed to live up to expectation. Rather, many of them have ended up as image laundering initiatives for the purpose of election, and also as windows of corruption through which funds are embezzled or misappropriated. Hence, many of the programmes lacked 
focus, continuity and due diligence. As a result, the leaders continued to get richer while the citizenry continued to get poorer. It is in the light of this that Chinua Achebe (1983) asserted that the trouble with Nigeria is simply and squarely a failure of leadership. There is nothing basically wrong with the Nigerian character. There is nothing wrong with the Nigerian land or climate or water or air or anything else. The Nigerian problem is the unwillingness or inability of its leaders to rise to the responsibility, to the challenge of personal example which are the hallmarks of true leadership.

\section{Recommendations and Conclusion}

The twin challenges of poverty and unemployment that face Nigeria as a nation cannot be surmounted without a credible and competent leadership. Therefore, Nigerians should be interested in how leaders emerge in the country. Nigerians should jettison the usual apathy towards elections. They should be interested in who governs them by getting involved in the process of voting credible candidates and also ejecting corrupt leaders from the system through the ballot box.

Leaders in the nation should also see themselves as servants who have been given the privilege to serve the people. They should see positions of leadership as a reposition of trust in them and not as a money making vocation. Service to the people and the people's welfare should be their watchword.

Corruption must be eradicated or reduced to the barest minimum. Funds must be utilised for the purposes for which they have been earmarked. The anti-corruption agencies like the EFCC, ICPC, Police etc should be alive to their responsibilities and ensure diligent prosecution of offenders in order to serve as deterrence to others.

All hands must be on deck to eradicate poverty and unemployment by the government at all levels. Conscious and concerted efforts must be made to create employment opportunities for the people and poverty alleviation programmes and initiatives that are sincere and not as windows of corruption should be aggressively embarked upon.

The people must demand accountability, transparency and good governance from the leaders. It is absolutely necessary to promote these qualities in governance if social progress, economic growth and national development must be achieved. These could be done through a more visible and active civil society organizations activities.

The nation must develop an institutional mechanism through which leaders emerge not based on religious or ethnic considerations, but on merit. This will ensure that only those who are driven by the passion to serve, knowledge and the burning desire to alleviate the sufferings of the citizenry emerge as leaders of the country.

The leaders in the nation should give priority to human capital development and infrastructural development especially in the rural areas, in order to alleviate absolute poverty in the rural areas.

In order to reduce unemployment in the polity, government at all levels should create the enabling environment for enterprenuership to thrive. This will make many of the youths to become job creators instead of job seekers.

The governments of foreign nations should step up efforts towards exposing corrupt government officials who steal the nation's money and hide it in foreign banks. This measure will effectively curb money laundering in Nigeria.

It remains a veritable fact of history that only good governance by credible leaders, can guarantee sustainable human development, economic empowerment and poverty reduction in any nation. Therefore, the emergence of good leaders to pilot the affairs of the nation is a conditio sine qua non if the scourges of poverty and unemployment are to be conquered, and if the Nigerian state is to attain her desired place in the comity of nations.

\section{References}

Achebe, Chinua. (1983). The Trouble with Nigeria. Enugu: Fourth Dimension Publishers.

Adamolekun, L. (2006) Politics, Bureaucracy and Development in Africa. Ibadan Spectrum Books Ltd, Ibadan.

Adebayo, A. (1999). Youth Unemployment and National Directorate of Employment Self Employment Programmes. Nigerian Journal Economics and Social Studies. 41(1), 81-102.

Adebayo, A. A. (2013). Youths' Unemployment and Crime in Nigeria: A Nexus and Implication for national Development. International Journal of Sociology and Anthropology, 5(8), 350-357.

Aigbokhan, B.E. (2000). Poverty, Growth and Inequality in Nigeria: A Case Study. African Economic Research Consortium (AERC). Nairobi, Kenya.

Ajufo, B.I. (2013). Challenges of Youth Unemployment in Nigeria: Effective Career Guidance as a Panacea. African Research Review, 7(1); 307-321.

Akanle, O and Olutayo, A. O. (2013). The Macro-Sociological Theories. In Olutayo, A. O. and Olayinka, O. (eds) Sociological Theory for African Students (First Edition). Ibadan: Ibadan University Press.

Awogbenle, A.C. and Iwuamadi, K.C. (2010). Youth Unemployment: Entrepreneurship Development Programme as an Intervention Mechanism. African Journal of Business Management, 4(6), 831-835.

Aiyedogbon, J.O. and Ohwofasa, B. O. (2012) Poverty and youth Unemployment in Nigeria, 1987-2011 International Journal of Business 
and Social Science 3(20) [Special Issue - October 2012]

Anazodo, R., Okoye, J.C. and Ezenwile, U. (2012). Leadership-Corruption: The Bane of Nigeria's Development. African Journal of Social Sciences, 2(3), 124-134.

Bass, B.M. and Stogdili, R.M. (1990) Handbook of Leadership. Free Press.

Damachi, N.A. (2001). Evaluation of past Policy Measures for Solving Unemployment Problems. Bullion, 25(4), 6-12. en.wikipedia.org/wiki/Structural_functionalism

Garba, A. (2006). Alleviating Poverty in Northern Nigeria. A paper presented at the Annual Convention of Zumunta Association, Minneapolis, MN, USA. July 28-29.

Hollister, R. and Goldstein, M. (1994). Reforming Labour Markets in the Near East. New York: International Center for Economic Growth. Human Development Report (1997): UNDP Publication.

Igwe, S. C. (2010). How Africa Underdeveloped Africa. Professional Publishers: Port-Harcourt.

Idowu, L. and Oyinlola, A. (eds) (2006). Standing Up Against Corruption, in Tell: Courage in Print. Lagos: Diamond Publications.

Jalan, J. and Ravallion, M. (1996). Transient Poverty in Rural Chinall. The World Bank Policy Research.Department, Poverty and Human Resources Division.

Lawal, T., Imokhuede, K. and Johnson, I. (2012). Governance Crisis and the Crisis of Leadership in Nigeria. International Journal of Academic Research in Business and Social Sciences, 2(7). 185-191.

Mullins, L.J. (1996). Management and Organisation Behaviour. London: Pitman Publishing.

National Assembly Statistics Book (2009)

National Bureau of Statistics (2009). Social Statistics in Nigeria. Abuja: The NBS Publication.

National Bureau of Statistics. (2011). Statistical News: Labour Force Statistics No. 476. Abuja: The NBS Publication.

National Policy on Poverty Eradication. (2000). Federal Republic of Nigeria.

Okafor, E. E. (2005). Executive Corruption in Nigeria: A Critical Overview of Its Socio-Economic Implications for Development. African Journal for Psychological Study of Social Issues, 8(1), 21-41.

Okafor, E.E. (2009). Development Crisis of Power Supply and Implications for Industrial Sector in Nigeria. Journal of Tribes and Tribals, $6(2), 83-92$

Okafor, E. E. (2011). Youth Unemployment and Implication for Stability of Democracy in Nigeria. Journal of Sustainable Development in Africa, 13(1), 358-373.

Okpi, A. (2014). Federal Government Spends N260bn on 30,000 Ex-Militants. Punch Newspaper, 16th February.

Okunmadewa, F.Y, Yusuf, S.A, Omonona, B.T. (2005); - Social Capital and Poverty Reduction In Nigeria, Revised Report Submitted to Africa Economic Research Consortium (AERC), Nairobi, Kenya.

Omotola, J.S. (2008). Combating Poverty for Sustainable Human Development in Nigeria: The Continuing Struggle. Journal of Poverty, 12(4), 496-517.

Osalor, P. (2010). Entrepreneurialism: The Solution to Combating Yout Crime in Nigeria. Vanguard, 28 March.

Raheem, M. I. (1993); "Nigeria for Africa: A Case for Labour Export", in Oyejide, T. A. and M. I. Obadan (eds), Applied Economics and Economic Policy - In Honour of Emmanuel C. Edozien, Ibadan University Press, Ibadan.

Walter, Rodney. (1972). How Europe Underdeveloped Africa. Washington, D.C: Howard University Press.

Salami, C.G.E. (2011). Enterpreneurship and Youth Unemployment in Nigeria: The Missing Link. Global Journal of Management and Business Research, 11(5). Version 1.0, April.

Segun, O. (2010). Galloping Poverty in Nigeria: An Appraisal of the Government's Interventionist Policies. Journal of Sustainable Development in Africa, 12(6). Clarion University of Pennsylvania, Clarion, Pennsylvania.

Sodangi, A. I. (2011). Rural Poverty and Agrarian Reforms. In Adedoyin, S. F. (ed.) Rural, Agricultural and Environmental Sociology in Nigeria. Nigerian Rural Sociological Association. Ibadan: Andkolad Publishers Nigeria Ltd.

Soyombo, O. (2006). Leadership and the Crisis of Legitimacy in Nigeria, in (eds.) Oyekanmi, F. and Soyombo, O. Society and Governance: The Quest for Legitimacy in Nigeria. Lagos: Irede Printers Ltd. pp. 269.

Todaro, M. (1992). Economics for a Developing World, (2nd Ed). England: Longman Group, U.K. Limited.

UNDP (2010) Human Development Report Nigeria 2008-2009. Achieving Growth with Equity.United Nations Development Programme.

Vanguardngr.com (December 17, 2013) 54\% of Nigerian youths were unemployed in 2012

Vanguard ( February 28, 2014). FG to spend N35.83bn on ex-militants in 2014.

World Bank (2001). World Development Report. New York: Oxford University Press

World Bank.(2008). World Development Report.

World Bank (2003). Engendering Development. New York: Oxford University Press.

Yusuf, H. A. (2010). Leadership Role and Good Governance in Nigeria. Available in www.imim-ng.org. Retrieved on $3^{\text {rd }}$ November 2014. 